\title{
Allelopathic activities of sponge extracts
}

\author{
Sebastian Engel, Joseph R. Pawlik* \\ Center for Marine Science, University of North Carolina at Wilmington, 5001 Masonboro Loop Road, Wilmington, \\ North Carolina 28409, USA
}

\begin{abstract}
Although there is anecdotal evidence for allelopathic interactions between benthic invertebrates engaged in spatial competition, only a few studies have established the involvement of chemical agents in field experiments. We have developed a technique in which crude organic extracts of marine sponges were incorporated into hard, stable gels that serve as a substratum for overgrowth by invertebrates in the field. Overgrowth organisms were secured to the center of assay plates and allowed to grow laterally over control gels and gels containing a crude organic sponge extract that was volumetrically equivalent to the concentration found in sponge tissues. Extracts of 20 species of Caribbean sponges were assayed in Florida using 3 overgrowth sponges: Tedania ignis, Lissodendoryx isodictialis, and Haliclona hogarthi. In addition, extracts of the sponge Aplysilla longispina were assayed in North Carolina using the tunicate Diplosoma listerianum as the overgrowth organism. The allelopathic effects varied between extracts of different sponge species, but were consistent across overgrowth organisms. Of the sponge extracts tested, $30 \%$ inhibited sponge growth (Amphimedon compressa, Aplysilla longispina, Aplysina cauliformis, Dysidea etheria, Ectyoplasia ferox, and Phorbas amaranthus), while 15\% promoted overgrowth (Agelas wiedenmeyeri, Geodia gibberosa, and Halichondria sp.). The remaining $55 \%$ of sponge extracts had no effect on sponge growth. The technique described herein represents a more ecologically relevant method than past techniques for assaying the allelopathic properties of extracts of marine organisms. Moreover, this study provides evidence that sponge metabolites may act as allomones by preventing overgrowth of some sponge species, and as both allomones and kairomones by enhancing overgrowth of others.
\end{abstract}

KEY WORDS: Allelopathy $\cdot$ Caribbean sponges $\cdot$ Chemical defenses $\cdot$ Overgrowth $\cdot$ Spatial competition $\cdot$ Kairomones $\cdot$ Allomones

\section{INTRODUCTION}

Chemical interactions between organisms have been reviewed extensively (e.g., Whittaker \& Feeny 1971, Kittredge et al. 1974, Rice 1985, Harborne 1988), and are divided into 2 classes that have either intraspecific or interspecific effects (Whittaker \& Feeny 1971). While pheromones are secondary metabolites that are synthesized by one organism to affect other individuals of the same species, allelopathic compounds are chemical agents that are produced by one organism to affect the health, growth, behavior, or population biology of organisms of other species (Whittaker \& Feeny 1971).

*Corresponding author. E-mail: pawlikj@uncwil.edu
While anecdotal evidence of allelochemical interactions date back as early as $300 \mathrm{BC}$, the term allelopathy was coined in 1937 by Molisch to describe biochemical interactions between terrestrial plants (Rice 1985 and references therein). Kittredge et al. (1974) were among the first to review allelopathy with regard to marine invertebrates. Given that spatial competition among sessile invertebrates is intense (Connell 1961, Dayton 1971, Paine 1974, Jackson 1977), many studies investigated potential allelopathic interactions among benthic invertebrates, yet few studies documented both the chemical and ecological aspects of allelopathy (reviewed in Pawlik 1993, Hay et al. 1998).

Some of the earliest investigations of presumed allelopathy in spatial competition among sessile marine invertebrates were strictly observational. Jackson \& Buss 
(1975) demonstrated that sponges were more likely to overgrow corals than vice versa, and that the spongecoral interface commonly exhibited zones of necrosis on the coral. Bryozoan competitors often showed similar fates in competitive interactions with sponges (Jackson \& Buss 1975). Allelopathic defense mechanisms have also been suggested between corals. Sheppard (1979) proposed that toxic exudates of hard corals such as Ctenella chagius are responsible for growth retardation in usually aggressive Acropora species, preventing adjacent growth up to $5 \mathrm{~cm}$. Other studies used manipulative experiments to document growth retardation, tissue necrosis, and mortality of corals in competitive interactions (Sammarco et al. 1983, 1985, La Barre et al. 1986). While these observational results suggest the involvement of chemical compounds in spatial interference competition, they only provide circumstantial evidence for allelopathy.

To gain a better understanding of allelopathy in spatial interference competition, the focus of some studies shifted to the isolation of chemical compounds believed to be responsible. Coll et al. (1982) developed a submersible sampling apparatus for the isolation of toxic terpenes released in situ by 2 species of soft corals. Sullivan et al. (1983) isolated siphonodictidine, a sesquiterpene that inhibits coral growth, from the mucus secreted by a burrowing sponge of the genus Siphonodictyon. Secretion of mucus by sponges was suggested as a mechanism for the concentration of allelochemicals near the sponge, preventing excessive dilution of the metabolites due to water flow (Jackson \& Buss 1975).

Thompson (1985) and Thompson et al. (1985) hypothesized that allelochemicals released from the sponge Aplysina fistularis protect it from overgrowth because the compounds cause behavioral modifications in laboratory assays conducted with adult and larval fouling organisms. Walker et al. (1985) measured the release rate of 2 potential allelochemicals from A. fistularis in the field, but it was unclear whether metabolite concentrations in moving seawater would ever reach the concentrations assayed in the lab (Thompson 1985, Thompson et al. 1985). Although these studies demonstrate a chemical basis for allelopathic interactions, the ecological functions of these compounds remain inconclusive without relevant field experiments.

To date, few studies have employed field experiments to demonstrate the involvement and direct effect of allelopathic chemicals. Porter \& Targett (1988) observed the liver sponge Plakortis halichondroides overgrowing the sheet coral Agaricia lamarcki and creating a zone of necrotic coral tissue when the 2 species were in direct contact with each other. To determine if tissue necrosis in A. lamarcki was the result of allelochemical secretions by $P$. halichondroides, they developed a field experiment in which extracts of the sponge were coated onto synthetic cellulose pads that were tied directly to the surface of the coral. Pads treated with extracts of $P$. halichondroides caused bleaching within $24 \mathrm{~h}$ while control pads produced no effect (Porter \& Targett 1988). Manipulative field experiments were also conducted with live tissue and extracts of the red alga Plocamium hamatum to investigate the necrotic effect of the red alga on the soft coral Sinularia cruciata (de Nys et al. 1991). Tissue necrosis of $S$. cruciata was only observed when the soft corals were in direct contact with the alga or plastic plants treated with extracts of the alga. Turon et al. (1996) developed a field experiment to investigate potential allelopathic effects of the sponge Crambe crambe on the tissue regeneration of the sponge Scapalina lophyropoda. Circular patches that were previously cut on large individuals of the sponge $S$. lophyropoda were exposed to freshly cut tissue of $C$. crambe or $S$. lophyropoda, while other individuals were unexposed as a control group. Tissue regeneration in the control individuals occurred faster than in those treated with $S$. lophyropoda, while individuals treated with C. crambe tissue never healed (Turon et al. 1996). Most recently, Thacker et al. (1998) used a method similar to that of Porter \& Targett (1988) to test the crude extract and purified 7-deacetoxyolepupuane from a Dysidea sp. in direct contact with a sponge of the genus Cacospongia. The extract and pure compound were incorporated at natural volumetric concentrations into agar that was poured onto strips of window screen. Treated and control strips were fastened around different branches of a single Cacospongia sp. colony. Thacker et al. (1998) found that both the crude extract as well as the pure secondary metabolite of Dysidea sp. caused necrosis of Cacospongia tissue within $7 \mathrm{~d}$, with no evidence of necrosis under control strips.

In this study, we employed a newly developed field technique to survey allelopathic effects of sponge extracts on the overgrowth of 3 sponges and 1 colonial tunicate. The technique involves the incorporation of crude organic extracts of marine sponges into hard, stable gels that serve as a substratum for overgrowth organisms. We tested the rate of release of crude sponge extracts from gels over a $21 \mathrm{~d}$ period in the field. Next, we surveyed the allelopathic properties of extracts of 20 different sponge species by comparing lateral growth differences of overgrowth organisms over paired extract-treated and control gels.

\section{MATERIALS AND METHODS}

Preparation of crude organic extracts. The sponge Aplysilla longispina was collected from the floating 
docks at Wrightsville Beach, North Carolina, USA. All other sponges were collected on shallow reefs and mangroves near Key Largo, Florida, USA. After collection, samples were taken back to the lab for immediate processing. For each sample, the volume of wet sponge tissue was measured by displacement in a 21 , graduated cylinder filled with 11 of seawater. Samples were then drained of excess seawater and placed into separate, air-tight, plastic freezer bags and frozen overnight. The frozen tissue of each sample was then cut into small cubes and lyophilized. Tissue samples were separately extracted in methanol for $24 \mathrm{~h}$. The resulting solution was filtered into a round bottom flask and the methanol was removed by rotary evaporation. The same tissue sample was then extracted a second time in 1:1 methanol:dichloromethane. After filtration the solution was added to the flask with the previous methanol-derived extract. The remaining 1:1 was then removed by rotary evaporation. The resulting crude extracts were then transferred into scintillation vials so that each vial contained an $80 \mathrm{ml}$ equivalent of the originally measured tissue. All extract samples were dried under high vacuum and stored under nitrogen in a freezer at $-20^{\circ} \mathrm{C}$ until used in assays.

Preparation of assay plates. Acrylic plates were used to construct a square assay plate measuring $15 \times$ $15 \times 0.8 \mathrm{~cm}$ and containing 4 gel wells in a 3 by 3 array (Fig. 1). Each well measured $5 \times 5 \times 0.8 \mathrm{~cm}$ and had a volume of $20 \mathrm{ml}$. In order to completely enclose all 4 wells, a single acrylic plate measuring $5 \times 5 \times 0.8 \mathrm{~cm}$ was placed in the center of the assay plate. Two opposing wells were used for extract-treated gels, while the remaining 2 were used for control gels. On each plate the overgrowth organism was allowed to overgrow paired extract-treated and control gels from the center plate.

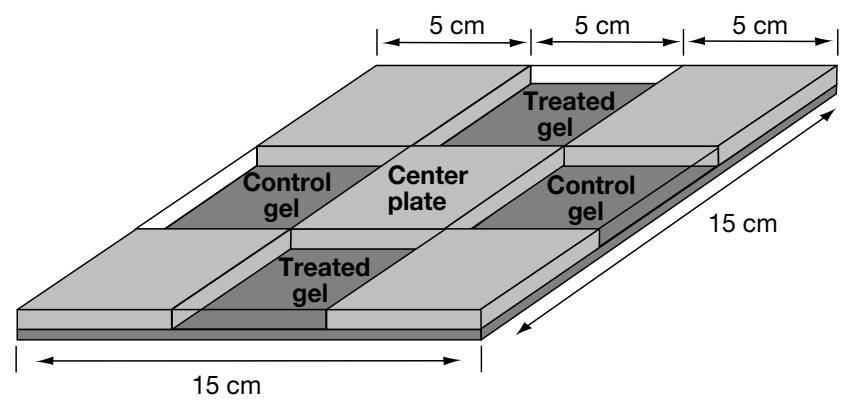

Fig. 1. Schematic diagram of assay plate containing four $20 \mathrm{ml}$ wells for paired treatment and control gels. Treatment wells were filled with gels containing a natural volumetric concentration of crude organic sponge extract. Control wells were filled with gels containing only a volumetric equivalent of the solvent used to re-suspend the extract for treated gels. The overgrowth organism on the center plate was allowed to laterally grow over the adjacent gels for $21 \mathrm{~d}$ in the field

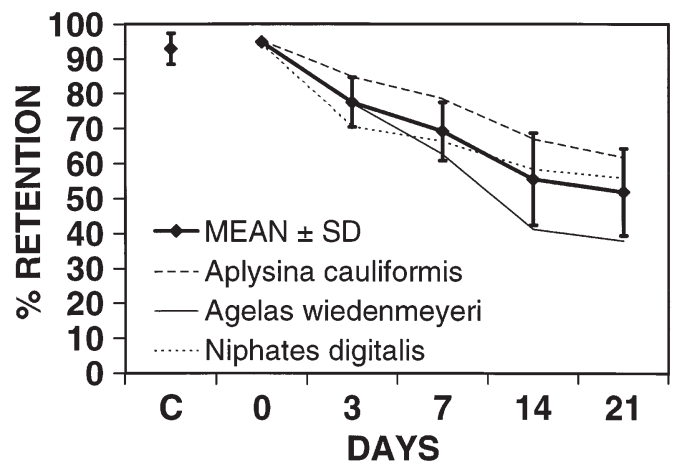

Fig. 2. Percentage retention of extracts of the sponges Aplysina cauliformis, Agelas wiedenmeyeri, and Niphates digitalis in gels over $21 \mathrm{~d}$ in the field. For each species, 2 replicate gels were extracted at each time interval. Control gels were kept in plastic bags at $5^{\circ} \mathrm{C}$ for $21 \mathrm{~d}$. Diffusion rates were similar across species, so the mean retention of all extracts was plotted (mean $\pm \mathrm{SD}, \mathrm{n}=6)$

Preparation of overgrowth organisms. The frog egg tunicate Diplosoma listerianum was chosen for assays at Wrightsville Beach, North Carolina. The acrylic center plates were mounted onto the underside of heavily fouled floating docks next to colonies of $D$. listerianum. After 2 to $4 \mathrm{~d} D$. listerianum began overgrowing the acrylic plates and covered the plates within 2 to $3 \mathrm{wk}$.

Lobes of the sponges Tedania ignis, Lissodendoryx isodictialis, and Haliclona hogarthi were collected from mangrove roots near Dusenbury Creek or near Sexton Cove, Key Largo, Florida. Each lobe, which measured at least $5 \times 5 \mathrm{~cm}$, was secured to the center square of a prepared assay plate with cable ties, and sponge tissue that extended beyond the edge of the center square was removed with a sharp knife.

Preparation of gels. Treatment gels were prepared by adding $1.5 \mathrm{~g}$ of Phytage ${ }^{\mathrm{TM}}$ to $80 \mathrm{ml}$ of distilled $\mathrm{H}_{2} \mathrm{O}$ and mixed thoroughly. The mixture was heated in a microwave oven for $1 \mathrm{~min}$. An aliquot of extract, re-

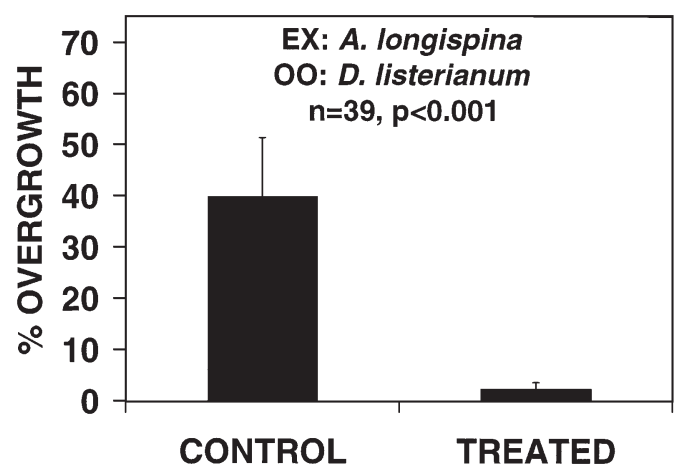

Fig. 3. Percentage overgrowth of the tunicate Diplosoma listerianum over paired control gels and gels treated with extracts of the sponge Aplysilla longispina (mean $\pm \mathrm{SD}, \mathrm{n}=39$, paired $t$-test on arcsine transformed data) ( $\mathrm{EX}=$ extract; $\mathrm{OO}=$ overgrowth organism) 
suspended in $10 \mathrm{ml}$ of methanol, was stirred into the hot mixture until homogenous. The resulting mixture was then poured into 2 opposing $20 \mathrm{ml}$ wells on each of 2 assay plates (Fig. 1). Control gels were prepared by adding $3 \mathrm{~g}$ of Phytagel ${ }^{\mathrm{TM}}$ to $80 \mathrm{ml}$ of distilled $\mathrm{H}_{2} \mathrm{O}$. A higher concentration of the inert gelling agent was necessary in control gels to maintain equal gel hardness between treatment and control gels. Gel hardness was measured using a gel tester (Marine Colloids GT-2, Springfield, NJ, USA). For the control gels, the mixture was heated, $10 \mathrm{ml}$ of methanol was added, and the gels were poured in the remaining two $20 \mathrm{ml}$ wells, as before.

Assessing retention of extracts in gels. Extracts of the sponges Agelas wiedenmeyeri, Aplysina cauliformis, and Niphates digitalis were used to assess the percentage retention of extracts in the gels over $21 \mathrm{~d}$ in the field. Before pouring the gels, the extract mass of each sample was recorded. Six sets of 2 gels for each sponge extract were prepared as detailed above. Four of the 6 sets were hung from a floating dock, while 2 sets were retained as controls. The first control set was stored at $5^{\circ} \mathrm{C}$ in a plastic bag throughout the $21 \mathrm{~d}$ assay period and subsequently re-extracted. The second set of control gels was reextracted immediately after being poured (Day 0). The remaining 4 sets were extracted after 3, 7, 14, and $21 \mathrm{~d}$ in the field and the mass of recovered extract was recorded. To compensate for salts and organics taken up by the gels in the field, the mass gained by paired control gels was subtracted from the mass recovered from treatment gels.

Running the assay. Assays with the tunicate Diplosoma listerianum as the overgrowth organism were conducted at the floating dock of the La Que Center for Corrosion Technology, Inc., Wrightsville Beach, North Carolina.

Six assay plates were deployed at any one time, with the experiment repeated to give 39 replicates (some plates were lost). Center plates overgrown with $D$. listerianum were fixed to the center of each assay plate
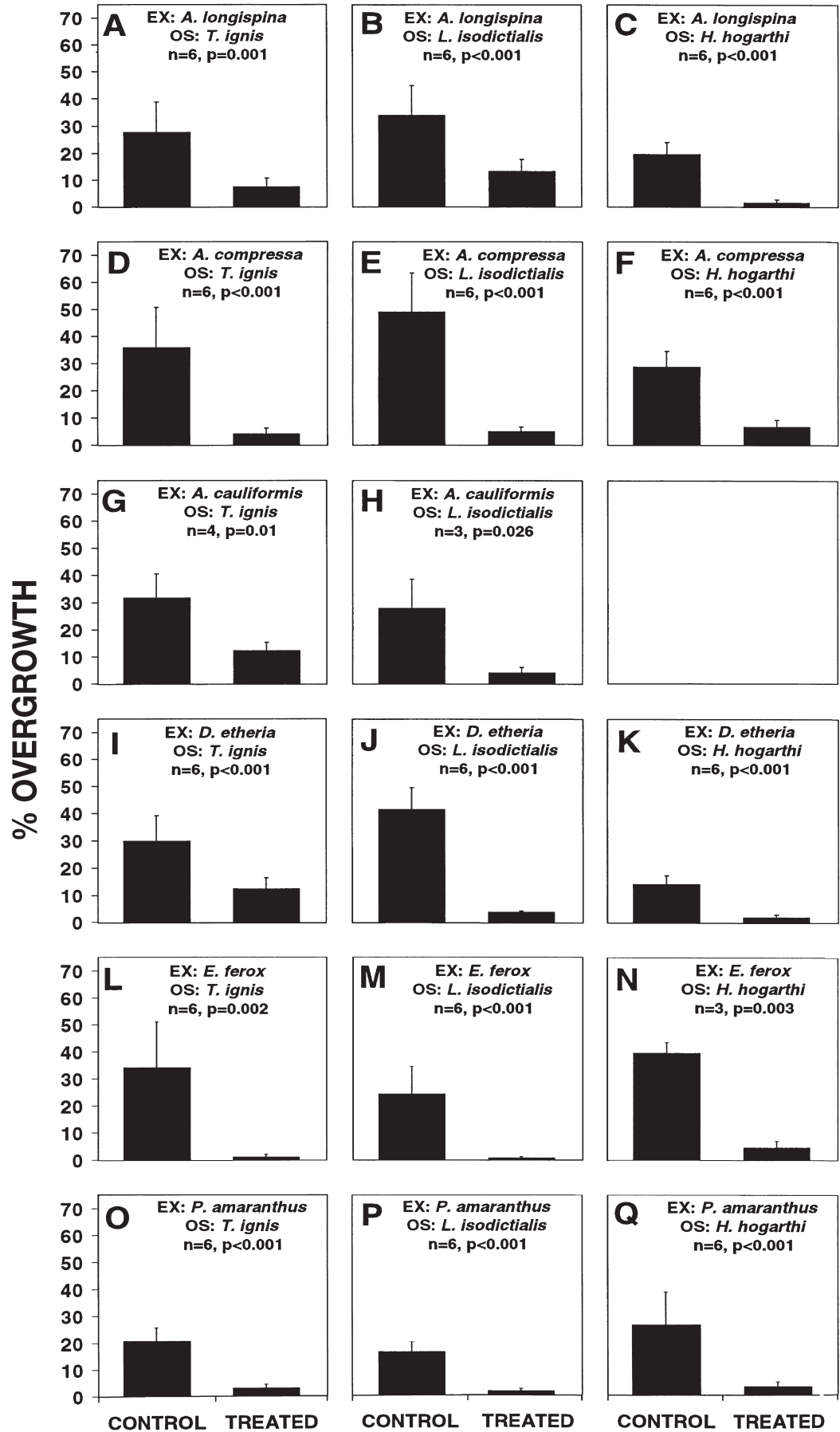

Fig. 4. Sponge extracts that inhibited the overgrowth of sponges. Percentage overgrowth of 3 species of sponges, Tedania ignis, Lissodendoryx isodictialis, and Haliclona hogarthi, over paired control and treatment gels. Treatment gels were treated with extracts of Caribbean sponges. Percentage overgrowth on paired control and extract-treated gels ( $\mathrm{EX}$ = extract; $\mathrm{OS}$ = overgrowth sponge).

See text for extract genera

with double-sided carpet tape. Each individual assay plate was hung with a monofilament line and swivel $30 \mathrm{~cm}$ below the water surface, allowing the plate to orient to water flow. All assay plates were left in the 
water for $21 \mathrm{~d}$. The lateral growth of $D$. listerianum over each of the 4 gels was scored by placing a $5 \times 5 \mathrm{~cm}$ piece of window screen over each gel and counting the number of squares in which the overgrowth organism appeared.

Assays with sponges as the overgrowth organisms were conducted in Florida Bay, Key Largo, Florida. Six replicate plates were prepared for each extract. The plates were hung $50 \mathrm{~cm}$ below the low tide level on a rope that was horizontally stretched between 2 mangrove prop roots. Assays were conducted and scored as described above. Percentage overgrowth was calculated by dividing the number of growth squares by the total number of squares, and multiplying by 100. A paired $t$-test, performed on arcsine-transformed data, was used to assess the significance of the difference in mean overgrowth on control versus extract-treated gels (Zar 1996).

\section{RESULTS}

Crude organic sponge extracts diffused gradually from gels (Fig. 2), with a mean of $51.9 \%$ of the starting material remaining after $21 \mathrm{~d}$ in the field. At the Wrightsville Beach, North Carolina, assay site, gels were exposed to the highest tidal flows that assay plates experienced in this study.

In assays conducted in North Carolina, the tunicate Diplosoma listerianum was inhibited from overgrowing gels containing a natural volumetric concentration of a crude extract of the co-occurring sponge Aplysilla longispina. In each case, the overgrowth by D. listerianum was significantly less on extract-treated gels relative to the overgrowth on control gels (Fig. 3).

In assays conducted in Florida, crude extracts of 6 sponge species inhibited sponge overgrowth (Fig. 4), extracts of 3 species promoted sponge overgrowth (Fig. 5), and extracts of 11 species had no effect (Fig. 6). Although the effects of the crude extracts revealed this level of interspecific variability, each extract gave a consistent result across the 3 overgrowth sponge species (Figs. 4 to 6). The mean percentage coverage of the 3 overgrowth sponges Tedania ignis, Lissodendoryx isodictialis, and Haliclona hogarthi over control gels was $31.8 \pm 8.6,35.9 \pm$ 9.1 , and $26.5 \pm 8.5 \%$, respectively.

\section{DISCUSSION}

Many studies have described putative allelopathic interactions among sessile marine invertebrates (Jackson \& Buss 1975, Sheppard 1979, Sammarco et al. 1983, Thompson et al. 1985), yet few have demonstrated the involvement and activity of chemical compounds in field experiments (Porter \& Targett 1988, Turon et al. 1996, Thacker et al. 1998). To date, all field assays have used tissue necrosis or regeneration as indicators for the allelopathic activity of applied treatments. This study is the first to use overgrowth by a sessile invertebrate to assess the allelopathic properties of crude organic extracts from invertebrates.

The technique described in this study represents a more ecologically relevant method for assessing the allelopathic activity of extracts. One of the main advantages of this technique is that gels made with Phytagel $^{\mathrm{TM}}$ remain hard and stable in the field. We found that both extract-treated and control gels provided a suitable overgrowth substratum for the sponges and tunicate used in this study. Henrikson (1996) also found that the bryozoan Schizoporella unicornis overgrew gels of this type. Other gelling agents such as acrylamide, alginic acid, and carageenan did
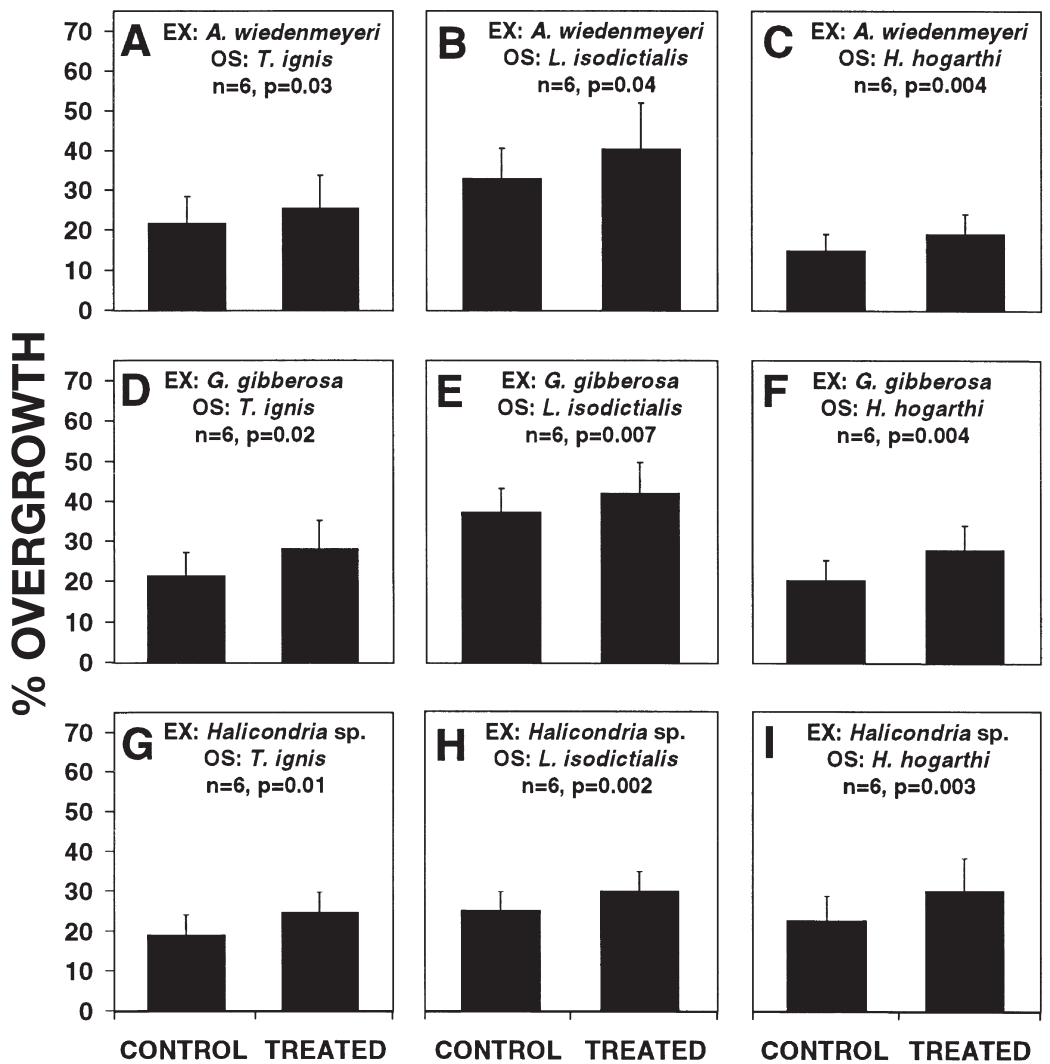

Fig. 5. Sponge extracts that promoted the lateral growth of sponges. Percentage overgrowth on paired control and extract-treated gels. Data presented as in Fig. 4 

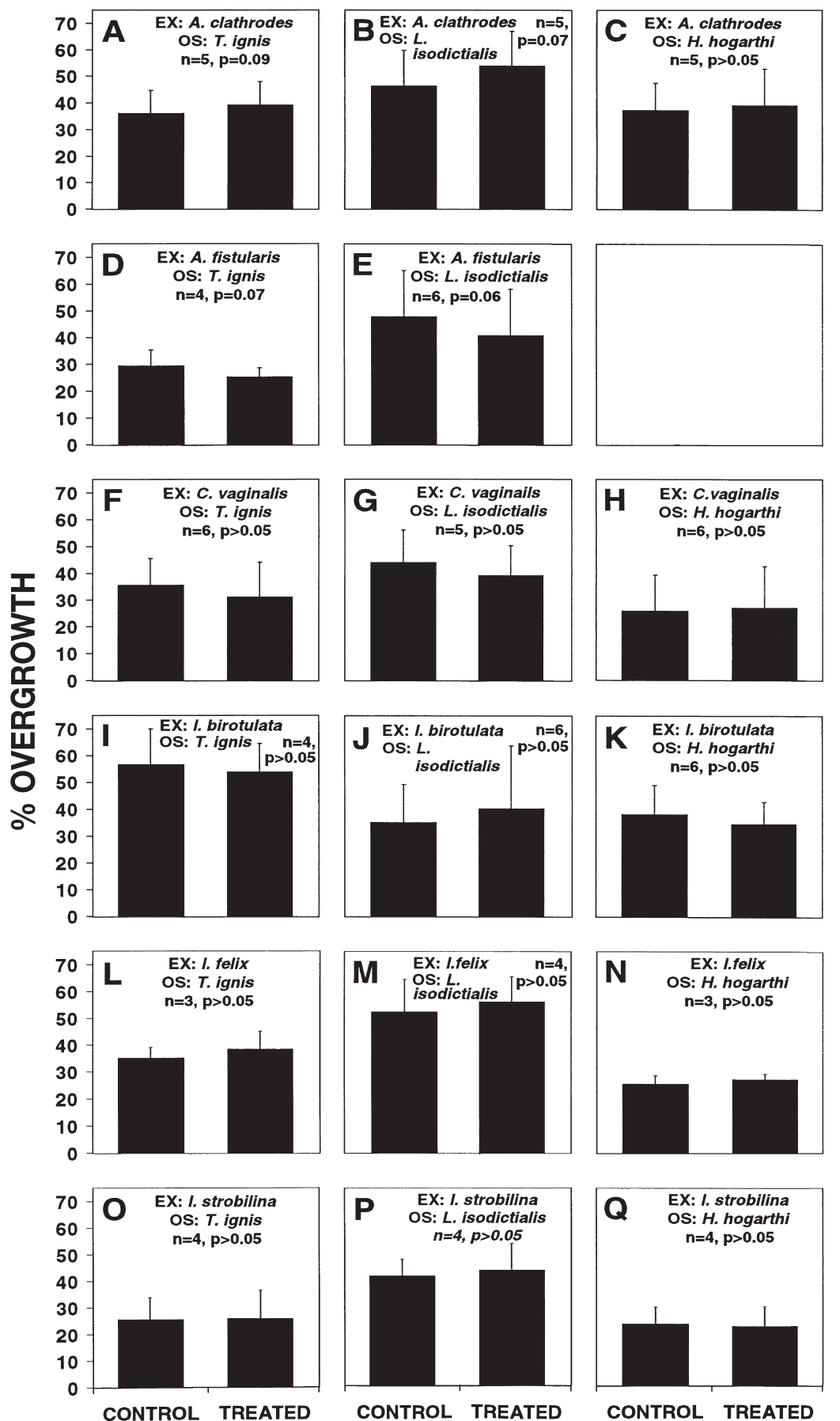

Fig. 6. Sponge extracts that had no effect on the overgrowth of sponges. Data presented as in Fig. 4

not solidify when extracts were added, or disintegrated under natural field conditions (Henrikson \& Pawlik 1995). In addition to gel hardness and stability, the 3dimensional structure of the overgrowth gel is advantageous over a 2-dimensional overgrowth surface (Bakus et al. 1991). Extracts that are taken from a 3- dimensional tissue and painted onto a 2-dimensional surface can potentially alter surface chemistry as well as the physical surface characteristics of the substratum (Mihm et al. 1981, Brewer 1984, Henrikson \& Pawlik 1995). Extracts incorporated into gels slowly diffuse from the substratum, in a manner that may mimic the slow release of metabolites from the surface of living organisms. Although little is known about the mechanisms of release of secondary metabolites by organisms producing them, there is evidence that some sponges exude secondary metabolites in the field (Thompson 1985, Walker et al. 1985, Nishiyama \& Bakus 1999).

Overgrowth organisms responded in 1 of 3 ways to sponge extracts. The majority of extracts (55\%) had no effect on overgrowth, while $30 \%$ inhibited and $15 \%$ promoted overgrowth. Despite the variability in the responses of overgrowth organisms to extracts of different sponge species, their responses were consistent within a treatment. Extracts of the sponges Amphemidon compressa, Aplysilla longispina, Aplysina cauliformis, Dysidea etheria, Ectyoplasia ferox, and Phorbas amaranthus all inhibited overgrowth (Fig. 4). Because none of these species are in the same sponge family, it appears that the production of overgrowth inhibiting metabolites is not taxonomically restricted. Moreover, each of these 6 extracts inhibited all 3 overgrowth sponges, suggesting that the effect is not directed in a speciesspecific manner. Extracts of the sponge A. longispina not only inhibited growth of the 3 sponge species, but also inhibited the growth of the colonial tunicate Diplosoma listerianum (Figs. 3 \& $4 \mathrm{~A}-\mathrm{C})$.

This study is part of a broader research program investigating the defensive functions of secondary metabolites from marine organisms. Henrikson \& Pawlik $(1995,1998)$ used gels of the same composition to conduct fouling assays in the field and determined that gels treated with an extract of Aplysilla longispina were less fouled than control gels. If secondary metabolites have a cost associated with production (Pawlik 

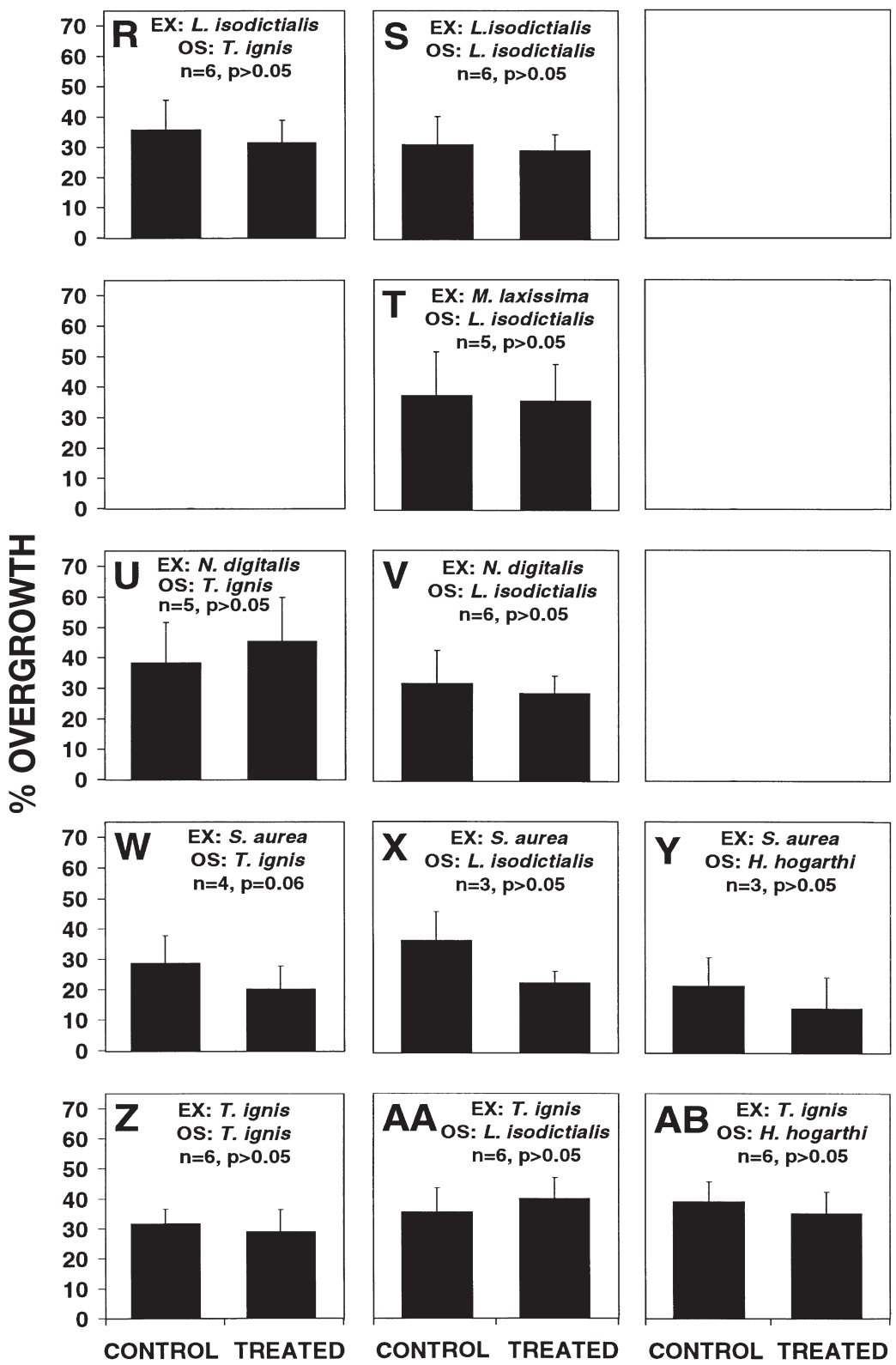

Fig. 6 (continued) al. 1999), and deterred feeding by the reef fish Thalassoma bifasciatum (Pawlik et al. 1995). Extracts of the sponge Ectyoplasia ferox inhibited all overgrowth sponges (Fig. 4L-N), and deterred predation by fish (Pawlik et al. 1995). Bioassay guided fractionation has yet to be performed to determine the metabolite or group of metabolites responsible for these defensive effects.

Extracts of the sponges Agelas wiedenmeyeri, Geodia gibberosa, and Halichondria sp. promoted overgrowth. Interestingly, Geodia gibberosa is frequently found to be thinly encrusted by the sponge Amphimedon erina. G. gibberosa is chemically undefended from fish predators (Pawlik et al. 1995) and is a preferred food of spongivorous fishes and turtles (Dunlap \& Pawlik 1996, 1998). A. erina, on the other hand, is strongly chemically defended from fish predation (Pawlik et al. 1995). Allelopathic agents are grouped into allomones, which benefit the organisms producing them, and kairomones, which benefit the organisms receiving them (Whittaker \& Feeny 1971). The relationship between $G$. gibberosa and A. erina may represent a mutualistic, associational defense. The secondary metabolites produced by G. gibberosa may act as both allomones and kairomones, in that promoting the overgrowth of $A$. erina benefits both $G$. gibberosa, by providing a protective, unpalatable covering, and A. erina, by providing space for growth.

The majority of sponge extracts had no allelopathic effect on overgrowth organisms, and the effects of these extracts in previous studies on bacterial growth and fish predation were incon-

1993), it seems probable that compounds may have evolved to function in multiple defensive roles. Although fouling and overgrowth are different processes, in that the former involves settlement of larval propagules, while the latter involves the growth of one adult organism over another, both play important roles in spatial competition.

Other sponge extracts may also have multi-functional defensive properties. Extracts of Amphimedon compressa not only inhibited the lateral growth of sponges in our assay (Fig. 4D-F), but also inhibited bacterial growth in antimicrobial assays (Newbold et sistent. While extracts of the sponges Aplysina fistularis, Ircinia felix, and Ircinia strobilina had no effect on overgrowth, they exhibited antimicrobial (Newbold et al. 1999) and fish antipredatory activity (Pawlik et al. 1995). In addition, extracts of the sponges Mycale laxissima and Smenospongia aurea also had no allelopathic effect on overgrowth, but were deterrent in fish feeding assays (Pawlik et al. 1995). On the other hand, extracts such as Callyspongia vaginalis, Iotrochota birotulata, and Niphates digitalis (Fig. 6F-K,U,V) neither inhibited overgrowth nor deterred feeding by Thalassoma bifasciatum (Pawlik et al. 1995). While 
these 3 sponges seem to lack any allelopathic secondary metabolites, it is interesting to note that they are among the most widely distributed and abundant sponges on Caribbean coral reefs (Pawlik et al. 1995). In addition, these sponges are frequently infused with polyps of zoanthids of the genus Parazoanthus. While it has been hypothesized that commensal zoanthids provide an associational defense (West 1976, Lewis 1982), Pawlik et al. (1995) did not find any evidence to suggest that zoanthids provided a chemical defense. While the ecological role of commensal zooanthids associated with sponges remains elusive, it appears that this interaction may be possible because these sponges lack allomones that inhibit the growth of such epibionts. Furthermore, sponges that inhibited overgrowth in our assays were never found to be overgrown by any zooanthids.

The absence of an allelopathic effect of an extract using this assay system does not rule out allelopathy by the living sponge. Despite its advantages over previous techniques, this assay system is nevertheless only an approximation of the delivery of sponge metabolites under natural conditions. Sponges that concentrate allelopathic metabolites near their surfaces, those that turn-over metabolites rapidly, or those that produce highly water-soluble metabolites might all have yielded inactive extracts using this assay system. In these respects, the results reported in this study represent a conservative estimate of allelopathy in Caribbean sponges. Moreover, this study provides good candidate species for bioassay-directed isolation of metabolites responsible for allelopathy. Future research directions also include the localization of allelopathic agents and the mechanisms of their release.

Acknowledgements. Funding for this research was provided by grants from the NOAA/National Undersea Research Program (UNCW9523, 9812) and from the National Science Foundation Biological Oceanography Program (OCE-9711255). Thanks to the staff of NOAA/NURC in Key Largo, Florida, for logistical support. Thanks also to Robyn Palmer, Greg McFall, Brett Waddell, Charlie Hileman, Dan Pisut, Will O'Neal, Tim Henkel, Kristen Whalen, Sarah Kelly, and David Snyder. In memory of Sophie. This is contribution No. 251 to UNCW's Center for Marine Science.

\section{LITERATURE CITED}

Bakus GJ, Schulte B, Jhu S, Wright M, Green G, Gomez P (1991) Antibiosis and antifouling in marine sponges: laboratory versus field studies. In: Rützler K (ed) New perspectives in sponge biology. Smithsonian Institution Press, Washington, DC, p 102-108

Brewer RH (1984) The influence of the orientation, roughness, and wettability of solid surfaces on the behavior and attachment of planulae of Cyanea (Cnidaria:Scyphozoa). Biol Bull 166:11-21

Coll JC, Bowden BF, Tapiolas DM, Dunlap WC (1982) In situ isolation of allelochemicals released from soft corals (Coelenterata: Octocorallia): a totally submersible sampling apparatus. J Exp Mar Biol Ecol 60:293-299

Connell JH (1961) Effects of competition, predation by Thais lapillus and other factors on natural populations of the barnacle Balanus balanoides. Ecol Monogr 31:61-104

Dayton PK (1971) Competition, disturbance, and community organization: the provision and subsequent utilization of space in a rocky intertidal community. Ecol Monogr 41: 351-389

de Nys R, Coll JC, Price IR (1991) Chemically mediated interactions between the red alga Plocamium hamatum (Rhodophyta) and the octogoral Sinularia cruciata (Alcyonacea). Mar Biol 108:315-320

Dunlap M, Pawlik JR (1996) Video-monitored predation by Caribbean reef fishes on an array of mangrove and reef sponges. Mar Biol 126:117-123

Dunlap M, Pawlik JR (1998) Spongivory by parrotfish in Florida mangrove and reef habitats. PSZN I: Mar Ecol 19: 325-337

Harborne JB (1988) Introduction to ecological chemistry, 3rd edn. Academic Press Inc, New York

Hay ME, Stachowicz JJ, Cruz-Rivera E, Bullard S, Deal MS, Lindquist N (1998) Bioassays with marine and freshwater macroorganisms. In: Haynes KF, Millar JG (eds) Methods in chemical ecology, Vol 2, Bioassay methods. Chapman \& Hall, New York, p 39-141

Henrikson AA (1996) A new antifouling assay method: seasonal variation in biofouling of gels containing extracts of marine organisms. MSc dissertation, University of North Carolina, Wilmington

Henrikson AA, Pawlik JR (1995) A new antifouling assay method: results from field experiments using extracts of four marine organisms. J Exp Mar Biol Ecol 194:157-165

Henrikson AA, Pawlik JR (1998) Seasonal variation in biofouling of gels containing extracts of marine sponges. Biofouling 12:245-255

Jackson JBC (1977) Competition on marine hard substrata. The adaptive significance of solitary and colonial strategies. Am Nat 111:743-767

Jackson JBC, Buss L (1975) Allelopathy and spatial competition among coral reef invertebrates. Proc Natl Acad Sci USA 72:5160-5163

Kittredge JS, Takahashi FT, Lindsay J, Lasker R (1974) Chemical signals in the sea: marine allelochemicals and evolution. Fish Bull US 74:1-11

La Barre SC, Coll JC, Sammarco PW (1986) Competitive strategies of soft corals (Coelenterata: Octocorallia). III. Spacing and aggressive interactions between alcyonaceans. Mar Ecol Prog Ser 28:147-156

Lewis SM (1982) Sponge-zoanthid associations: functional interactions. Smithson Contrib Mar Sci 12:465-474

Mihm JW, Banta WC, Loeb GI (1981) Effects of adsorbed organic and primary fouling films on bryozoan settlement. J Exp Mar Biol Ecol 54:167-179

Newbold RW, Jensen PR, Fenical W, Pawlik JR (1999) Antimicrobial activity of Caribbean sponge extracts. Aquat Microb Ecol 19:279-284

Nishiyama GK, Bakus G (1999) Release of allelochemicals by three tropical sponges (Demospongiae) and their toxic effects on coral substrate competitiors. Mem Queensl Mus 44:411-417

Paine RT (1974) Intertidal community structure. Experimental studies on the relationship between a dominant competitor and its principal predator. Oecologia 15:93-120

Pawlik JR (1993) Marine invertebrate chemical defenses. Chem Rev 93:1911-1922 
Pawlik JR, Chanas B, Toonen RJ, Fenical W (1995) Defenses of Caribbean sponges against predatory reef fish. I. Chemical deterrency. Mar Ecol Prog Ser 127:183-194

Porter JW, Targett NM (1988) Allelochemical interactions between sponges and corals. Biol Bull 175:230-239

Rice EL (1985) Allelopathy-An overview. In: Copper-Driver GA, Swain T, Conn EE (eds) Recent advances in phytochemistry, Vol 19, Chemically mediated interactions between plants and other organisms. Plenum Press, New York, p 81-105

Sammarco PW, Coll JC, La Barre S, Willis B (1983) Competitive strategies of soft corals (Coelenterata: Octocorallia): allelopathic effects on selected scleractinian corals. Coral Reefs 1:173-178

Sammarco PW, Coll JC, La Barre S (1985) Competitive strategies of soft corals (Coelenterata: Octocorallia). II. Variable defensive responses and susceptibility to scleractinian corals. J Exp Mar Biol Ecol 91:199-215

Sheppard C (1979) Interspecific aggression between reef corals with reference to their distribution. Mar Ecol Prog Ser 1:237-247

Sullivan B, Faulkner DJ, Webb L (1983) Siphonodictidine, a metabolite of the burrowing sponge Siphonodictyon sp. that inhibits coral growth. Science 221:1175-1176

Editorial responsibility: Otto Kinne (Editor),

Oldendorf/Luhe, Germany
Thacker RW, Becerro MA, Lumbang WA, Paul VJ (1998) Allelopathic interactions between sponges on a tropical reef. Ecology 79:1740-1750

Thompson JE (1985) Exudation of biologically-active metabolites in the sponge Aplysilla fistularis. I. Biological evidence. Mar Biol 88:23-26

Thompson JE, Walker RP, Faulkner DJ (1985) Screening and bioassays for biologically-active substances from forty marine sponge species from San Diego, California, USA. Mar Biol 88:11-21

Turon X, Becerro MA, Uriz MJ, Llopis J (1996) Small-scale association measures in epibenthic communities as a clue for allelochemical interactions. Oecologia 108:351-360

Walker RP, Thompson JE, Faulkner DJ (1985) Exudation of biologically-active metabolites in the Sponge Aplysina fistularis. II. Chemical evidence. Mar Biol 88:27-32

West DA (1976) Aposematic coloration and mutualism in sponge-dwelling tropical zoanthids. In: Mackie GO (ed) Coelenterate ecology and behavior. Plenum Press, New York, p 443-452

Whittaker RH, Feeny PP (1971) Allelochemics: chemical interactions between species. Science 171:757-770

Zar JH (1996) Biostatistical analysis, 3rd edn. Prentice-Hall Inc, Upper Saddle River, NJ

Submitted: April 12, 2000; Accepted: August 15, 2000

Proofs received from author(s): September 10, 2000 